\title{
Pengaruh Model CTL (Contextual Teaching Learning) dengan Media Pohon Hitung terhadap Hasil Belajar Materi Operasi Hitung
}

\author{
Yulinda Amalia ${ }^{1 *}$, Rasiman ${ }^{2}$ \\ ${ }^{12}$ Jurusan Pendidikan Guru Sekolah Dasar, FIP, Universitas PGRI Semarang, Indonesia
}

\author{
ARTICLEINFO \\ Article history: \\ Received 18 February \\ 2019 \\ Received in revised form \\ 20 March 2019 \\ Accepted 20 April 2019 \\ Available online 20 May \\ 2019 \\ Kata Kunci: \\ CTL(Contextual Teaching \\ Learning), Meningkatkan \\ Hasil Belajar Siswa \\ Keywords: \\ CTL(Contextual Teaching \\ Learning), Improve Student \\ Learning Outcomes
}

\begin{abstract}
A B S T R A K
Penelitian ini dilakukan untuk meningkatkan hasil belajar siswa kelas III SD Kusuma Bhakti Semarang melalui model pembelajaran CTL (Contextual Teaching Learning) dengan media pohon hitung pada materi operasi hitung. Penelitian ini adalah penelitian kuantitatif menggunakan Quasi Experimental Design dengan jenis Nonequivalent Control Grup Design. Populasi dalam penelitian ini adalah siswa kelas III-A dan III-B SD Kusuma Bhakti Semarang berjumlah 35 siswa. Instrumen yang digunakan adalah wawancara, dokumentasi dan tes. Analisis menggunakan uji normalitas, uji homogenitas dan (uji-t). Hasil penelitian yang dilakukan dapat dismpulkan bahwa model CTL dengan media pohon hitung dapat meningkatkan hasil belajar pada materi operasi hitung siswa kelas III. Hal ini dapat dilihat dari hasil perhitungan uji-t dengan taraf signifikan $=5 \%$ dengan menggunakan uji-t didapatkan nilai sebesar $T_{\text {hitung }}=3,1325$ dengan $T_{\text {tabel }}=1,667$ karena $T_{\text {hitung }}>$ $T_{\text {tabel }}$ yaitu $3,1325>1,667$. Dengan demikian Ho ditolak dan $\mathrm{Ha}$ artinya model CTL dengan bantuan media pohon hitung berpengaruh terhadap hasil belajar materi operasi hitung siswa kelas III SD Kusuma Bhakti Semarang. Hal ini juga dibuktikan dengan perbedaan rata-rata nilai posttest kelas eksperimen sebesar 79,34 lebih tinggi dari kelas kontrol sebesar 70,34 dengan ketuntasan kelas eksperimen sebesar $91,42 \%$ yang telah mencapai kriteria minimal $80 \%$ dibandingkan dengan kelas kontrol sebesar $71,42 \%$.
\end{abstract}

\section{A B S T R A C T}

This research was conducted to improve the learning outcomes of third grade students of SD Kusuma Bhakti Semarang through the CTL (Contextual Teaching Learning) learning model with a calculated tree media in the counting operation material. This research is a quantitative experimental research using Quasi Experimental Design with the type of Nonequivalent Control Design Group. The population in this study were students of class III-A and III-B SD Kusuma Bhakti Semarang totaling 35 students. The instruments used were interviews, documentation and tests. Analysis using the normality test, homogeneity test and (uji-t). The results of the research carried out can be concluded that the CTL model with a calculated tree media can improve learning outcomes in count III operating material. This can be seen from the results of the t-test calculation with a significant level $=5 \%$ using the t-test obtained value of $T_{\text {hitung }}=3.1325$ with $T_{\text {tabel }}=1.667$ because $T_{\text {hitung }}>T_{\text {tabel }}$ which is $3.1325>1.667$. Thus $\mathrm{Ho}$ is rejected and Ha means the CTL model with the help of calculating tree influences on the learning outcomes of calculating operating material for Grade III students of SD Kusuma Bhakti Semarang. This is also evidenced by the difference in the average posttest value of the experimental class of 79.34 higher than the control class of 70.34 with the completeness of the experimental class of $91.42 \%$ which has reached the criteria of at least $80 \%$ compared to the control class of $71.42 \%$.

Copyright (C) Universitas Pendidikan Ganesha. All rights reserved

\footnotetext{
${ }^{1}$ Corresponding author.

E-mail addresses: Lindaamalia130@yahoo.com (Yulinda Amalia)
} 


\section{Pendahuluan}

Seiring dengan perkembangan jaman yang sangat maju, ilmu pengetahuan, seni, dan teknologi juga menjadi sangat canggih. Persaingan dalam segala aspek di dunia menjadi sangat tinggi. Perkembangan ilmu pengetahuan, seni, dan teknologi ini akan berpengaruh terhadap semua aspek yang ada di dunia, salah satunya yaitu aspek pendidikan.

Menurut Mugiraharjo (2018) Pendidikan merupakan salah satu sarana yang menentukan untuk mencapai tujuan pembangunan nasionalyaitu mewujudkan suatumasyarakat adil dan makmur dalam wadah Negara Kesatuan Republik Indonesia. Sistem pendidikan nasional mempunyai tujuan sebagai alat yang amat penting dalam perjuangan mencapai cita-cita tujuan bangsa Indonesia dalam mencerdaskan kehidupan bangsa Indonesia dan manusia Indonesia seutuhnya, yaitu mengembangkan potensi peserta didik agar menjadi manusia yang beriman dan bertakwa kepada Tuhan Yang Maha Esa, berakhlak mulia, sehat, berilmu, cakap, kreatif, mandiri, dan menjadi warga Negara yang demokratis serta bertanggung jawab. Pendidikan bagi kehidupan umat manusia merupakan kebutuhan yang sangat mutlak harus dipenuhi sepanjang hayat. Pendidikan merupakan sebuah wujud nyata bagi peserta didik menuju ke arah hidup yang lebih baik. Seperti yang terkandung dalam UU Sisdiknas Nomor 20 tahun 2003 tentang Sistem Pendidikan Nasional Bab I Pasal 1 ayat 1 yang menyebutkan, bahwa: "Pendidikan adalah usaha sadar dan terencana untuk mewujudkan suasana belajar proses pembelajaran agar peserta didik secara aktif mengembangkan potensi dirinya untuk memiliki kekuatan spiritiual keagamaan, pengendalian diri, kepribadian, kecerdasan, akhlak mulia, serta ketrampilan yang diperlukan dirinya, masyarakat, bangsa dan negara".

Agar pelaksanaan pembelajaran dapat berjalan dengan baik, diperlukan tenaga pendidik yang profesional. Dalam hal ini guru harus bisa memahami karakteristik peserta didik dalam proses pembelajaran. Proses pembelajaran di kelas harus dilakukan banyak variasi agar peserta didik tertarik. Peran dari model dan media pembelajaran sangatlah menunjang hasil belajar peserta didik.

Pada pendidikan terdapat proses pembelajaran yang didalamnya terjadi sebuah proses belajar mengajar. Menurut Slameto dalam (Hamdani, 2011:20) "Belajar adalah suatu proses yang dilakukan seseorang untuk memperoleh perubahan tingkah laku yang baru secara keseluruhan, sebagai hasil pengalamannya sendiri dalam interaksi dengan lingkungannya." Menurut DiVesta dan Thompson dalam (Suyono, 2014:13) menyatakan bahwa "belajar adalah perubahan tingkah laku yang relatif menetap sebagai hasil dari pengalaman. Dari beberapa pengertian di atas dapat disimpulkan bahwa belajar adalah kegiatan memperoleh pengetahuan yang dihasilkan dari pengalaman dan pengamatan".

Untuk mencapai tujuan pendidikan dan pembelajaran diperlukan adanya kurikulum yang digunakan untuk mengatur proses pembelajaran di sekolah. Pada jenjang pendidikan dasar khususnya sekolah dasar, kurikulum yang digunakan saat ini yaitu Kurikulum Tingkat Satuan Pendidikan (KTSP).

Salah satu mata pelajaran yang ada di sekolah dasar yang perlu ditingkatkan kualitasnya adalah matematika. Di sekolah dasar merupakan tempat siswa mengenal konsep-konsep dasar matematika. Depdiknas dalam (Ali Hamzah dan Muhlisrarini 2014:48) menyatakan bahwa "matematika berasal dari akar kata mathema artinya pengetahuan, mathanein artinya berpikir atau belajar. Dalam kamus Bahasa Indonesia diartikan matematika adalah ilmu tentang bilangan hubungan antara bilangan dan prosedur operasional yang digunakan dalam penyelesaian masalah mengenai bilangan".

Mengingat pentingnya matematika dalam pengembangan generasi melalui kemampuan inovasi sains dan teknologi di era globalisasi, maka tidak dibiarkan adanya anak-anak muda yang buta matematika. Karena pentingnya peranan mata pelajaran matematika, maka sudah semestinya apabila prestasi belajar matematika maksimal. Berdasarkan observasi dan wawancara dengan Ibu Ratna, S.Pd selaku guru wali kelas III-A di SD Kusuma Bhakti Semarang, siswa kelas III cenderung mempunyai perilaku kurang bersemangat dalam menerima mata pelajaran matematika yang dianggap sulit oleh para siswa pada materi operasi hitung dan mata pelajaran matematika hasilnya masih banyak yang di bawah nilai ketuntasan 65 berdasarkan Kriteria Ketuntasan Minimal (KKM). Selain itu matematika menjadi ditakuti karena dianggap sulit, hal ini disebabkan karena kebanyakan guru dalam menyampaikan pembelajaran matematika hanya menggunakan metode ceramah dan jarang menggunakan media sehingga anak sulit memahami konsep dalam pelajaran matematika.

Menurut Hidayati (2012) Pembelajaran lebih identik dengan membaca, menghafal, dan mengingat materi pelajaran. Demikian juga mengajar diibaratkan hanya sebagai proses transfer pengetahuan dari guru kepada peserta didik. Guru hanya memaknai mengajar sebagai menyampaikan materi. Hal ini dapat diamati dalam praktik pembelajaran sehari-hari. Dampak dari hal tersebut adalah, peserta didik menjadi pasif, mudah bosan, mengantuk, dan guru mendominasi aktivitas pembelajaran. Kurangnya guru dalam memberikan sebuah inovasi dalam pembelajaran di kelas membuat tujuan pembelajaran tidak dapat tercapai dengan baik. Dalam mengajar guru membutuhkan sebuah model pembelajaran di mana guru 
dapat melaksanakan proses pembelajaran sesuai model pembelajaran yang digunakan. Menurut Joyce and Weil dalam (M.Fathurrohman 2017:30) mendefinisikan bahwa "model pembelajaran adalah suatu rencana atau suatu pola yang digunakan sebagai pedoman dalam melaksanakan pembelajaran di kelas atau pembelajaran dalam tutorial dan untuk menentukan perangkat-perangkat pembelajaran". Model pembelajaran dapat dijadikan pola pilihan, artinya para guru boleh memilih model pembelajaran yang sesuai dan efisien untuk mencapai tujuan pendidikannya.

Salah satu model pembelajaran yang dapat diterapkan dalam proses pembelajaran yaitu model pembelajaran CTL (Contextual Teaching Learning). Menurut Jamaluddin (2015) model pembelajaran CTL merupakan proses pembelajaran yang bertujuan untuk membantu siswa dalam berkarya, mengaplikasikan pengetahuan dengan menghubungkan pelajaran dalam konteks kehidupan nyata. Memberikan kesempatan kepada siswa pengalaman berproses dan menghasilka karya, sehingga siswa aktif, kreatif dan cepat dalam memahami materi yang telah disampaikan guru. Menurut Hasibuan (2014) model pembelajaran kontekstual (Contekstual Teaching and Learning) adalah merupakan proses pembelajaran yang holistik dan bertujuan membantu siswa untuk memahami makna materi ajar dan mengaitkannya dengan konteks kehidupan mereka sehari-hari (konteks pribadi, sosial dan kultural), sehingga siswa memiliki pengetahuan/ keterampilan yang dinamis dan fleksibel untuk mengkonstruksi sendiri secara aktif pemahamannya. Menurut Nurhadi (2002) dalam Rusman (2014:189) Pembelajaran kontekstual (Contextual Teaching Learning) merupakan konsep belajar yang dapat membantu guru mengaitkan antara materi yang diajarkannya dengan situasi dunia nyata siswa dan mendorong siswa membuat hubungan antara pengetahuan yang dimilikinya dengan penerapannya dalam kehidupan mereka sebagai anggota keluarga dan masyarakat.

Proses pembelajaran tidak hanya didasari dengan model pembelajaran maupun pelaksanaan pembelajaran. Selama proses pembelajaran berlangsung para pendidik membutuhkan sebuah alat bantu atau biasa yang disebut sebagai media pembelajaran. Media pembelajaran digunakan yaitu media pohon hitung untuk membantu para pendidik dalam mengajar siswa di dalam kelas maupun diluar kelas, sehingga pendidik akan lebih terbantu dalam menyampaikan materi.

Penelitian sebelumnya yang dilakukan oleh Erlina, (2018) tentang Meningkatkan Kemampuan Kognitif Mengurutkan Bilangan 1-10 melalui Media Pohon Hitung Anak kelompok B di TK Baptis Setia Bakti Kota Kediri. Dapat disimpulkan bahwa pembelajaran dengan menggunakan media pohon hitung terbukti berhasil dan mampu meningkatkan kemampuan kognitif anak didik dalam mengurutkan bilangan 1-10 sehingga hipotesis dalam penelitian ini dapat diterima.

Penelitian sebelumnya yang dilakukan oleh Ayuningtyas, Mutiara (2018) tentang Pengaruh Model Pembelajaran CTL terhadap Kemampuan Pemecahan Masalah Matematika Siswa Kelas III SD Negeri 2 Pucang Banjarnegara. Dapat disimpulkan bahwa terdapat pengaruh yang signifikan antara keaktifan belajar siswa terhadap kemampuan pemecahan masalah siswa pada model pembelajaran CTL dimana diperoleh $r_{\text {hitung }}=0,5081$, dan $r_{\text {tabel }}=0,444$. Hal ini menunjukkan $r_{\text {hitung }}>r_{\text {tabel }}$, maka Ho ditolak dan Ha diterima berarti ada pengaruh Dapat disimpulkan bahwa bahwa terdapat pengaruh yang signifikan antara model pembelajaran CTL terhadap kemampuan pemecahan masalah yaitu sebesar $26 \%$.

Penelitian yang lain juga pernah diteliti oleh Faresya, Alfina Fatma (2018) tentang pengaruh model pembelajaran CTL dengan media Pop Up terhadap hasil belajar IPS siswa kelas III SDN Jambean 03 Pati. Hasil penelitian ini menyatakan bahwa dengan model pembelajaran CTL dengan media Pop Up terhadap hasil belajar IPS meningkat. Hasil posttest menunjukan bahwa persentase ketuntasan belajar klasikal kelompok eksperimen (85\%) sedangkan kelompok kontrol (54\%), serta berdasarkan uji t (dua pihak) diperoleh $T_{\text {hitung }}=3,366$ dan $T_{\text {tabel }}=2,06$. Karena nilai $T_{\text {hitung }}>T_{\text {tabel }}$ yaitu 3,366 $>2,06$ maka Ho ditolak. Dapat disimpulkan bahwa ada pengaruh model pembelajaran CTL dengan media Pop Up dalam meningkatkan hasil belajar IPS.

Penelitian ini bertujuan untuk mengetahui Untuk mengetahui pengaruh model pembelajaran CTL (Contextual Teaching Learning) dengan media pohon hitung terhadap hasil belajar materi operasi hitung siswa kelas III SD Kusuma Bhakti semester genap 2018/2019. Berdasarkan permasalahan dan fakta-fakta dan teori diatas, penelitian berjudul pengaruh model pembelajaran CTL (Contextual Teaching Learning) dengan media pohon hitung terhadap hasil belajar materi operasi hitung siswa kelas III SD Kusuma Bhakti Semarang.

\section{Metode}

Desain penelitian yang digunakan dalam penelitian ini adalah desain Eksperimen Metode penelitian ini menggunakan Quasi Experimental Design dengan jenis Nonequivalent Control Grup Design. 
Bentuk Nonequivalent Control Group Design adalah sebagai berikut :

\begin{tabular}{|c|c|c|}
\hline$O_{1}$ & $X$ & $O_{2}$ \\
\hline $\mathrm{O}_{3}$ & & $O_{4}$ \\
\hline
\end{tabular}

Gambar 1. Desain Penelitian

Menurut Sugiyono (2017:112) bentuk Nonequivalent Control Group Design hampir sama dengan pretest-posttest control group design, hanya pada desain ini kelompok eksperimen maupun kelompok kontrol tidak dipilih secara random. Dalam penelitian kelompok eksperimen akan diberikan treatmen atau perlakuan, yaitu dengan menggunakan model CTL (Contextual Teaching Learning) dengan media pohon hitung, sedangkan kelompok kontrol merupakan kelompok yang tidak diberikan perlakuan. Pengaruh perlakuan adalah (02-01) - (04-03) (Sugiyono 2017: 116).

Instrumen yang digunakan dalam penelitian ini dirancang untuk mengetahui perbedaan hasil belajar siswa sebelum diberi perlakuan dan setelah diberi perlakuan menggunakan model pembelajaran CTL dengan media pohon hitung. Dalam penelitian ini menggunakan metode tes, tes digunakan untuk mendapatkan data hasil belajar siswa pada materi operasi hitung matematika. Data yang dimaksud adalah hasil belajar kognitif siswa kelas III SD Kusuma Bhakti Semarang. Tes dilakukan sebelum proses belajar mengajar dilaksanakan (pretest) dan sesudah proses belajar mengajar (posttest). Hasil ini juga digunakan untuk mengetahui pengaruh model pembelajaran CTL dengan media pohon hitung.

Selanjutnya yang harus dikerjakan adalah teknik analisis data yang terdiri dari Uji Normalitas yang dilakukan untuk mengetahui bahwa sampel berasal dari populasi berdistribusi normal. Dalam tahap berikutnya melakukan Uji Homogenitas untuk mengetahui apakah kelas tersebut homogen dengan kriteria Ha ditolak dan Ho diterima. Yang terakhir yaitu Uji Hipotesis yang digunakan untuk menjawab hipotesis penelitian dengan menggunakan rumus Uji T dengan kriteria $T_{\text {hitung }}>T_{\text {tabel }}$.

\section{Hasil dan Pembahasan}

Hasil penelitian dilaksanakan di kelas III SD Kusuma Bhakti Semarang tahun pelajaran 2018/2019 dengan judul penelitian "Pengaruh Model Pembelajaran CTL (Contextual Teaching Learning) dengan Media Pohon Hitung terhadap Hasil Belajar Materi Operasi Hitung Siswa Kelas III SD Kusuma Bhakti Semarang". Penelitian dilaksanakan pada tanggal 8- 15 April 2019. Sebelum dilaksanakan penelitian, penulis melakukan soal uji coba instumen di SD Islam Al-Fattah Semarang pada kelas III. Soal yang diuji cobakan sebanyak 30 butir soal pilihan ganda pada mata pelajaran matematika pada materi operasi hitung. Hasil dari uji coba soal dianalisis untuk mengetahui jumlah soal yang memenuhi kriteria validitas, reliabilitas, daya pembeda dan taraf kesukaran. Jumlah 30 soal uji coba yang memenuhi kriteria valid, reliabel, daya pembeda dan taraf kesukaran adalah 15 soal, dari 15 soal uji coba yang valid maka dijadikan soal pretest dan soal posttest.

Penelitian ini merupakan penelitian kuantitatif yang menggunakan desain Quasi Ezpermental dengan bentuk Nonequivalent Control Group Design. Rancangan penelitian dapat digambarkan sebagai berikut: Menurut Sugiyono (2017:112) bentuk Nonequivalent Control Group Design hampir sama dengan pretest-posttest control group design, hanya pada desain ini kelompok eksperimen maupun kelompok kontrol tidak dipilih secara random. Sampel penelitian berasal dari semua populasi kelas III yang berjumlah 70 siswa yang terdiri dari kelas III-A sebanyak 35 siswa sebagai kelas eksperimen dan kelas IIIB sebanyak 35 siswa sebagai kelas kontrol. Dalam penelitian kelompok eksperimen kelas III-A akan diberikan perlakuan, yaitu dengan menggunakan model CTL (Contextual Teaching Learning) dengan media pohon hitung, sedangkan kelompok kontrol kelas III-B merupakan kelompok yang tidak diberikan perlakuan.

Data dalam penelitian ini terdiri dari dua macam yaitu data awal dan data akhir. Data awal diambil dari nilai pretest kelas eksperimen maupun kelas kontrol sebelum proses pembelajaran berlangsung, sedangkan data akhir diambil dari nilai posttest kelas ekperimen yang mendapatkan perlakuan dan kelas kontrol yang tidak mendapatkan perlakuan. Nilai rata-rata hasil belajar siswa pretest dan posttest pada kelas kontrol dan kelas eksperimen dapat dilihat pada tabel dibawah ini: 
Tabel 1. Nilai Rata-Rata Pretest dan Posttest

\begin{tabular}{clcc}
\hline No & \multicolumn{1}{c}{ Kelas } & Rata-rata Pretest & Rata-rata Posttest \\
\hline 1. & Kontrol & 56,46 & 70,57 \\
2. & Eksperimen & 55,57 & 79,34 \\
\hline
\end{tabular}

Berdasarkan data yang terdapat pada tabel 1. didapatkan nilai rata-rata pretest dan posttest menunjukkan skor rata-rata hasil belajar siswa. Pada kelas kontrol yang awalnya nilai pretest memiliki rata-rata sebesar 56,46 dan setelah dilakukan posttest didapatkan nilai rata-rara sebesar 70,57, sedangkan pada kelas eksperimen yang awalnya nilai pretest memiliki rata-rata sebesar 55,57 dan setelah dilakukan posttest didapatkan nilai rata-rata sebesar 79,34. Terdapat perbandingan skor rata-rata antara sebelum diberikan perlakuan menggunakan model CTL dan media pohon hitung dalam pembelajaran matematika pada materi operasi hitung dan sesudah diberikan perlakuan menggunakan model CTL dan media pohon hitung dalam pembelajaran matematika pada materi operasi hitung mengalami peningkatan hasil belajar siswa. Dengan demikian menunjukkan bahwa kelas yang dikenai model pembelajaran CTL menggunakan media pohon hitung pada materi operasi hitung mendapatkan nilai rata - rata lebih tinggi dibandingkan dengan kelas yang menggunakan model pembelajaran konvensional.

Data akhir diperoleh dari nilai posttest yang didapatkan setelah pembelajaran dengan perlakuan menggunakan model CTL dan media pohon hitung dalam pembelajaran matematika pada materi operasi hitung dan kelas yang menggunakan model pembelajaran konvensional dapat dilihat pada tabel dibawah ini:

Tabel 2. Hasil Nilai Posttest

\begin{tabular}{clcc}
\hline No & \multicolumn{1}{c}{ Sumber Variasi } & Kelas Kontrol & Kelas Eksperimen \\
\hline 1. & Nilai Terendah & 40 & 53 \\
2. & Nilai Tertinggi & 86 & 100 \\
3. & Rata-rata Kelas & 70,57 & 79,34 \\
\hline
\end{tabular}

Berdasarkan Tabel 2. diketahui hasil nilai posttest kelas kontrol dengan nilai terendah yaitu 40 dan nilai tertinggi yaitu 86 dengan nilai rata-rata 70,57 sedangkan pada kelas eksperimen dengan nilai terendah yaitu 53 dan nilai tertinggi yaitu 100 dengan nilai rata-rata 79,34. Kemudian disajikan dalam bentuk diagram hasil posttest siswa kelas III sebagai berikut:

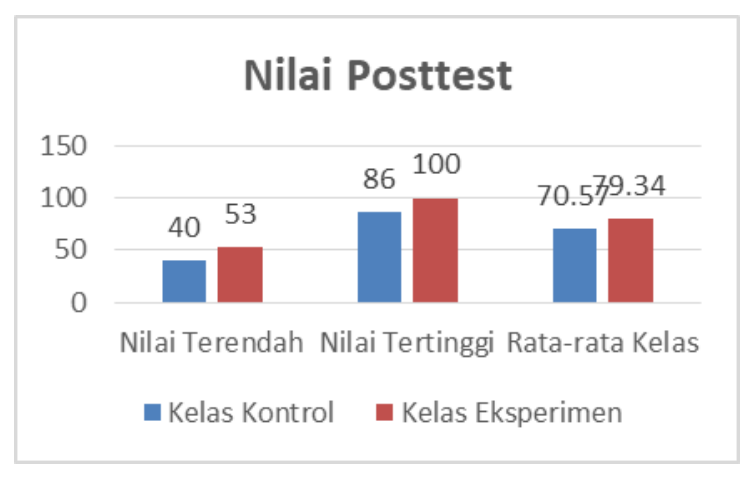

Gambar 2. Nilai Posttest Kelas Kontrol dan Kelas Eksperimen

Berdasarkan hasil analisis nilai kelas kontrol dan eksperimen dari nilai awal dan nilai akhir terdapat perbedaan rata-rata hasil pembelajaran kelas yang mendapatkan perlakuan menggunakan model pembelajaran CTL dan media operasi hitung dengan kelas yang tidak mendapatkan perlakuan sehingga dapat disimpulkan bahwa kelas yang mendapatkan perlakuan mendapatkan hasil yang lebih baik.

Tujuan dari penggunaan model CTL ini peserta didik diharapkan agar dalam belajar tidak hanya sekedar menghafal tetapi perlu dengan adanya pemahaman dan mendorong peserta didik mengaitkan materi dengan kehidupan sehari-hari. Dalam penggunaan model CTL ini terdapat beberapa kendala berkaitan dengan waktu yang cukup lama dalam pembentukan kelompok dan beberapa siswa yang enggan berkelompok dengan teman yang lain. Namun, permasalahan tersebut tidak menjadi penghalang dalam menerapkan model CTL ini. 
Penggunaan model CTL pada kelas eksperimen terbukti berpengaruh dan siswa lebih senang serta aktif dalam belajar matematika. Hal ini sesuai dengan prinsip pembelajaran kontekstual menurut Rusman (2014 : 193-197), ada tujuh prinsip pembelajaran kontekstual yang harus dkembangkan oleh guru, yaitu: 1) Konstruktivisme, bahwa pengetahuan dibangun oleh manusia sedikit demi sedikit yang dihasilkan diperluas melalui konteks yang terbatas; 2) Menemukan, upaya menemukan akan memberikan penegasan bahwa pengetahuan dan ketrampilan serta kemampuan-kemampuan yang lain yang diperlukan hasil menemukan sendiri; 3) Bertanya, unsur bertanya dalam CTL harus difasilitasi oleh guru, kebiasaan siswa untuk bertanya atau kemampuan guru dalam menggunakan kemampuan bertanya yang baik; 4) Masyarakat belajar, membiasakan melakukan kerja sama dan memanfaatkan sumber belajar dari temanteman belajarnya; 5) Permodelan, tahap pembuatan model dapat dijadikan alternatif untuk mengembangkan pembelajaran agar siswa bisa memenuhi harapan siswa secara menyelurh, dan membantu mengatasi keterbatasan yang dimiliki oleh para guru; 6) Refleksi, cara berpikir tentang apa yang baru terjadi atau baru saja dipelajari; 7) Penilaian sebenarnya, penilaian sebagai bagian internal dari pembelajaran memiliki fungsi yang amat menentukan untuk mendapatkan informasi kualitas proses dan hasil pembelajaran melalui penerapan CTL.

Alasan yang signifikan antara keaktifan peserta didik dalam kelas kontrol dan kelas eksperimen disebabkan oleh langkah-langkah yang terdapat dalam model CTL yaitu dengan menemukan sendiri pengetahuan, menciptakan masyarakat belajar dan mengembangkan sifat ingin tahu siswa melalui memunculkan pertanyaan-pertanyaan. Hal ini sesuai dengan kelebihan pembelajaran kontekstual yang dikemukakan oleh Shoimin (2017:44), yaitu : 1) Pembelajaran kontesktual dapat menekankan aktivitas berpikir siswa secara penuh, baik fisik maupun mental; 2) Pembelajaran kontekstual dapat menjadikan siswa belajar bukan dengan menghafal, melainkan proses berpengalaman dalam kehidupan; 3) Kelas dalam kontekstual bukan sebagai tempat untuk memperoleh informasi, melainkan sebagai tempat untuk menguji data hasil temuan mereka di lapangan; 4) Materi pelajaran ditentukan oleh siswa sendiri, bukan hasil pemberian dari orang lain.

Dengan menggunakan model CTL, siswa dapat pada kelas eksperimen menjadi lebih aktif, siswa sangat bersemangat selama proses pembelajaran dan siswa tidak canggung untuk bertanya, sehingga siswa mudah dalam menyelesaikan soal-soal materi operasi hitung. Penggunaan model CTL ini diterapkan di kelas eksperimen dengan media pohon hitung, media pohon hitung menggunakan sebatang pohon beringin yang terbuat dari papan triplek dan desain gambar pohon bringin dapat mempermudahkan materi operasi hitung penjumlahan dan pengurangan.

Pembelajaran konvensional merupakan teknik pembelajaran yang biasa digunakan oleh guru dalam kegiatan pembelajaran. Pembelajaran dengan metode ini biasanya didominasi guru dengan metode ceramah namun terkadang peserta didik menjadi lebih pasif dan membuat peserta didik bosan selama pembelajaran berlangsung. Dalam pembelajaran matematika, apabila peserta didik didominasi oleh guru dalam pembelajarannya, maka peserta didik merasa enggan untuk mengikuti pembelajaran karena tidak bisa mengembangkan kemampuannya secara optimal. Oleh karena itu, kebanyakan peserta didik menganggap matematika sebagai pelajaran yang sulit dan membuat hasil belajar peserta didik tersebut menurun.

Berdasarkan penelitian yang sudah dilakukan di kelas III SD Kusuma Bhakti Semarang bahwa model pembelajaran CTL menggunakan media pohon hitung dalam pembelajaran matematika pada materi operasi hitung lebih berpengaruh dibandingkan dengan pembelajaran dengan menggunakan metode ceramah.

Perbedaan hasil belajar siswa pada mata pelajaran matematika yang nampak antara kelas kontrol dan eksperimen adalah pembelajaran dengan menggunakan metode ceramah dan pembelajaran dengan menggunakan model CTL dengan menggunakan media pohon hitung. Hasil rata-rata hasil belajar siswa pada kelas ekperimen lebih tinggi dibandingkan dengan kelas kontrol. Dari perbedaan ini dapat disimpulkan bahwa pembelajaran dengan menggunakan model pembelajaran CTL dengan menggunakan media pohon hitung memberikan pengaruh terhadap kemampuan kognitif hasil belajar siswa mata pelajaran matematika siswa kelas III SD Kusuma Bhakti Semarang dibandingkan dengan menggunakan metode ceramah.

Penelitian sebelumnya yang dilakukan oleh Ayuningtyas, Mutiara (2018) tentang Pengaruh Model Pembelajaran CTL terhadap Kemampuan Pemecahan Masalah Matematika Siswa Kelas III SD Negeri 2 Pucang Banjarnegara. Dapat disimpulkan bahwa terdapat pengaruh yang signifikan antara keaktifan belajar siswa terhadap kemampuan pemecahan masalah siswa pada model pembelajaran CTL dimana diperoleh $r_{\text {tabel }}=0,5081$, dan $r_{\text {tabel }}=0,444$. Hal ini menunjukkan $r_{\text {hitung }}>r_{\text {tabel }}$, maka Ho ditolak dan Ha diterima berarti ada pengaruh Dapat disimpulkan bahwa bahwa terdapat pengaruh yang signifikan antara model pembelajaran CTL terhadap kemampuan pemecahan masalah yaitu sebesar $26 \%$. 
Penelitian yang lain juga pernah diteliti oleh Faresya, Alfina Fatma (2018) tentang pengaruh model pembelajaran CTL dengan media Pop Up terhadap hasil belajar IPS siswa kelas III SDN Jambean 03 Pati. Hasil penelitian ini menyatakan bahwa dengan model pembelajaran CTL dengan media Pop Up terhadap hasil belajar IPS meningkat. Hasil posttest menunjukan bahwa persentase ketuntasan belajar klasikal kelompok eksperimen (85\%) sedangkan kelompok kontrol (54\%), serta berdasarkan uji t (dua pihak) diperoleh $T_{\text {hitung }}=3,366$ dan $T_{\text {tabel }}=2,06$. Karena nilai $T_{\text {hitung }}>T_{\text {tabel }}$ yaitu 3,366 $>2,06$ maka Ho ditolak. Dapat disimpulkan bahwa ada pengaruh model pembelajaran CTL dengan media Pop Up dalam meningkatkan hasil belajar IPS. Sedangkan penelitian yang dilakukan pada tanggal 8- 15 April 2019 dengan judul pengaruh model pembelajaran CTL (Contextual Teaching Learning) dengan media pohon hitung terhadap hasil belajar materi operasi hitung siswa kelas III SD Kusuma Bhakti Semarang diperoleh hasil $T_{\text {tabel }}$ dk pembilang $(\mathrm{n} 1+\mathrm{n} 2-2)=68, \alpha=5 \%$. Ternyata $T_{\text {hitung }}>T_{\text {tabel }}$ yaitu 3,1325 $>1,6675$. maka Ho ditolak, sehingga dapat disimpulkan bahwa kelas eksperimen ada pengaruh model pembelajaran CTL dengan media pohon hitung terhadap hasil belajar materi operasi hitung siswa kelas III SD Kusuma Bhakti Semarang.

\section{Simpulan dan Saran}

Menurut Sugiyono (2017:112) bentuk Nonequivalent Control Group Design hampir sama dengan pretest-posttest control group design, hanya pada desain ini kelompok eksperimen maupun kelompok kontrol tidak dipilih secara random. Dalam penelitian kelompok eksperimen akan diberikan treatmen atau perlakuan, yaitu dengan menggunakan model CTL (Contextual Teaching Learning) dengan media pohon hitung, sedangkan kelompok kontrol merupakan kelompok yang tidak diberikan perlakuan. Pengaruh perlakuan adalah (02-01) - (04-03) (Sugiyono 2017: 116).

Instrumen yang digunakan dalam penelitian ini dirancang untuk mengetahui perbedaan hasil belajar siswa sebelum diberi perlakuan dan setelah diberi perlakuan menggunakan model pembelajaran CTL dengan media pohon hitung. Dalam penelitian ini menggunakan metode tes, tes digunakan untuk mendapatkan data hasil belajar siswa pada materi operasi hitung matematika. Data yang dimaksud adalah hasil belajar kognitif siswa kelas III SD Kusuma Bhakti Semarang. Tes dilakukan sebelum proses belajar mengajar dilaksanakan (pretest) dan sesudah proses belajar mengajar (posttest). Hasil ini juga digunakan untuk mengetahui pengaruh model pembelajaran CTL dengan media pohon hitung.

Selanjutnya yang harus dikerjakan adalah teknik analisis data yang terdiri dari Uji Normalitas yang dilakukan untuk mengetahui bahwa sampel berasal dari populasi berdistribusi normal. Dalam tahap berikutnya melakukan Uji Homogenitas untuk mengetahui apakah kelas tersebut homogen dengan kriteria Ha ditolak dan Ho diterima. Yang terakhir yaitu Uji Hipotesis yang digunakan untuk menjawab hipotesis penelitian dengan menggunakan rumus Uji T dengan kriteria $T_{\text {hitung }}>T_{\text {tabel }}$.

\section{Daftar Rujukan}

Arikunto, Suharsimi. 2016. Dasar-dasar Evaluasi Pendidikan. Jakarta: Bumi Aksara.

Arsyad, Azhar. 2014. Media Pembelajaran. Jakarta: PT Raja Grafindo Persada.

Ayuningtyas, Mutiara. 2018. Pengaruh Model Pembelajaran CTL terhadap Kemampuan Pemecahan Masalah Matematika Siswa Kelas III SD Negeri 2 Pucang Banjarnegara. Skripsi. FIP. Pendidikan Guru Sekolah Dasar. Universitas PGRI Semarang.

Erlina. 2018.Meningkatkan Kemampuan Kognitif Mengurutkan Bilangan 1-10 melalui Media Pohon Hitung Anak kelompok B di TK Baptis Setia Bakti Kota Kediri. Jurnal PINUS Vol.3 No. 2 Maret 2018.

Faresya, Alfina Fatma. 2018. Pengaruh Model Pembelajaran CTL dengan Media Pop Up terhadap Hasil Belajar IPS Siswa Kelas III SDN Jambean 03 Pati. Skripsi. FIP. Pendidikan Guru Sekolah Dasar. Universitas PGRI Semarang.

Fathurrohman. 2017. Model-Model Pembelajaran Inovatif. Yogyakarta: Ar-Ruzz Media.

Hamdani. 2011. Strategi Belajar Mengajar. Bandung: CV Pustaka Setia. 
Hamzah Ali, dan Muhlisrarini. 2014. Perencanaan Strategi Pembelajaran Matematika. Jakarta: Rajawali.

Hasibuan, H. M. Idrus. 2014. Model Pembelajaran CTL (Contextual Teaching and Learning). Logaritma Vol. II, No.01 Hal. 1-12. Tersedia Pada : http://jurnal.iainpadangsidimpuan.ac.id/index.php/LGR/article/download/214/195.

Herpratiwi. 2016. Teori Belajar dan Pembelajaran. Yogyakarta: Media Akademi.

Hidayati, Yulia Maftuhah. 2012. Pembelajaran Penjumlahan Bilangan Pecahan dengan Metode Contextual Teaching and Learning (CTL) di SD Muhammadiyah Program Khusus, Kota Barat, Surakarta. Jurnal Penelitian Humaniora, Vol. 13, No. 1, Hal. 86-94. Tersedia Pada : http://journals.ums.ac.id/index.php/humaniora/article/viewFile/919/632.

Isrok'atun dan Amelia Rosmala. 2018. Model Pembelajaran Matematika. Jakarta: PT. Budi Aksara.

Jamaluddin S., M. Iqbal, I Gusti Putu Asto B. 2015. Pengaruh Model Pembelajaran CTL (Contextual Teaching and Learning) terhadap Hasil Belajar Siswa pada Kompetensi Dasar Menerapkan Macam - Macam Gerbang Dasar Rangkaian Logika di SMK Negeri 7 Surabaya. Jurnal Pendidikan Teknik Elektro. Volume 04 Nomor 01 Hal. 73-79. Tersedia Pada : https://jurnalmahasiswa.unesa.ac.id/index.php/jurnal-pendidikan-teknikelektro/article/view/10344.

Karwono dan Heni Mularsih. 2018. Belajar dan Pembelajaran serta Pemanfaatan Sumber Belajar. Depok: Rajawali.

Mugiraharjo, Hartoyo. 2018. Penerapan Model Pembelajaran Contextual Teaching and Learning (CTL) untuk Meningkatkan Mutu Pembelajaran PPKn. Jurnal Pendidikan Madrasah, Volume 3, Nomor 2, Hal. 359-365. Tersedia Pada : suka.ac.id/tarbiyah/index.php/JPM/article/view/2147.

Purnomo, Wahyu Yoppy. 2014. Serial Matematika untuk PGSD Bilangan Cacah dan Bulat Sebuah Tinjauan Konsep dan Instruksional dalam Pembelajaran. Bandung: Alfabeta.

Purwanto. 2009. Evaluasi Hasil Belajar. Yogyakarta: Pustaka Pelajar.

Rusman. 2016. Model-Model Pembelajaran. Jakarta: Rajawali.

Shoimin, Ari. 2017. 68 Model Pembelajaran Inovatif dalam Kurikulum 2013. Yogjakarta: Ar-Ruzz Media.

Sudjana. 2005. Metode statistika. Bandung: PT. Tarsito.

Sugiyanto. 2010. Model-Model Pembelajaran Inovatif. Surakarta: Yuma Pustaka.

Sugiyono.2017. Metode Penelitian Pendidikan(Pendekatan kuantitatif, kualitatif,dan R\&D). Bandung: Alfabeta.

Suprijono, Agus. 2017. Cooperative Learning. Yogyakarta: Pustaka Pelajar.

Suyono, Hariyanto. 2014. Belajar dan Pembelajaran Teori dan Konsep Dasar. Bandung: PT Remaja Rosdakarya.

Sukmadinata, Nana Syaodih. 2013. Metode Penelitian Pendidikan. Bandung: PT Remaja Rosdakarya. 